Article

\title{
Achieving Ecological Objectives
}

\section{Henrik Josefsson}

Faculty of Law, University of Uppsala, Box 256, 75105 Uppsala, Sweden;

E-Mail: henrik.josefsson@jur.uu.se; Tel.: +46-18-4712008

Received: 3 April 2012; in revised form: 15 May 2012 / Accepted: 14 June 2012 /

Published: 2 July 2012

\begin{abstract}
The legal objective for surface water in the EU is 'good ecological status', as established by the Water Framework Directive, with a timeframe of 15, 21 or 27 years. To reach this objective, suitable legal instruments are needed, and quality standards are among the instruments intended to improve the ecological status. However, both the Directive and quality standards are founded on reductionism, risking an over-application of over-simplified concepts, probably reducing biological diversity. A realistic and more appropriate timeframe for river basin rehabilitation would be around 100 years, emphasizing several concerns, such as the importance of encompassing the entire life history of species, the shift in human perceptions, the systemic unity of humans and ecosystems, environmental irreducibility, site-specific reference points, and the divergence of the assessment of water quality and the general ecological status of a river basin. From a legal standpoint, a century emphasizes a temporal agreement and a normative commitment to the generations to come. Ecologically, a century time-scale gives enough time for the processes of evolution, dispersal and recolonization and succession to re-establish stable, more diverse biological communities in physically rehabilitated habitats and river basins, whereas the present timetable for achievement of the ecological objectives does not.
\end{abstract}

Keywords: EU water framework directive; ecological objectives; ecological quality standards; environmental quality standards, ecological standards; reductionism; holism; ecosystem management 
Now in our real changing world, the situation and, with it, the possibilities, and thus the propensities, change all the time. They certainly may change if we, or any other organisms, prefer one possibility to another; or if we discover a possibility where we have not seen one before. Our very understanding of the world changes the conditions of the changing world; and so do our wishes, our preferences, our motivations, our hopes, our dreams, our phantasies, our hypotheses, our theories. Even our erroneous theories change the world, although our correct theories may, as a rule, have a more lasting influence. All this amounts to the fact that determinism is simply mistaken: all its traditional arguments have withered away and indeterminism and free will have become part of the physical and biological sciences.

Karl Popper [1]

\section{Introduction}

The EU is unique in its transboundary laws, institutions, and cooperation in the field of environmental matters. With its quasi-federal structure, the EU has managed to go beyond the rigid distinction between international and national law that prevails in intergovernmental cooperation [2].

Historically, legislation concerning water has been some of the most developed and progressive in European Community law. This trend persists, and the most significant and momentous developments are taking place with regard to aquatic species and ecosystems, and therefore, their principles and assessment methods may eventually be applied to other sectors of environmental law, and to non-aquatic biodiversity [3]. Therefore, aquatic ecosystems, and water in general, may be perceived as testing grounds for contemporary regulations [3].

In the EU, the current ecological objective for surface water is 'good ecological status', established by the Water Framework Directive [4-6]. Through this institutionalization of ecosystem-based objectives, community water policy is supposed to become functionally oriented towards sustainable development (e.g. Articles 1 and 4 emphasize sustainability) [7,8]. To reach this objective, suitable legal instruments are needed, and quality standards have been discussed and emphasized as one set of legal instruments with the potential to bring about an improved environmental status [3,9-11].

For example, quality standards have led to successful reductions of concentrations of toxic substances in bodies of water, and may be useful for addressing environmental problems related to air and water quality, which are linked to human health [10,12-14]. The establishment of quality standards signified an important change in environmental regulations; for example, they take their point of departure in the conditions of a body of water, are based on the precautionary principle, and are legally manageable. Nonetheless, when trying to manage coupled social and ecological systems, quality standards appear both ineffective and unsuited to addressing the difficulties facing aquatic ecosystems, for instance, destruction and alteration of aquatic habitats, or mitigation of organic pollution, given that the rationale for this tool is established by baselines of simple thresholds and fixed elements/possibilities, rather than propensities $[1,15,16]$. This results in a legal instrument poorly equipped to address status changes in ecosystems, and therefore also unsuited to attaining the legal objectives of 'good ecological status'. It becomes important to focus on, and question the path dependence created by the current regulations, by acknowledging the risks inherent in treating diverse, 
dynamic, and complex ecosystems as though they were identical, which gives rise to alienation and placelessness [17]. There is also the risk that environmental problems, such as the loss of biodiversity and ecosystem services, may be masked by the good intentions and beliefs inherent in the application of a quality standard.

The problematic aspects of quality standards emphasize the differences between traditional environmental laws, normally concerned with the contamination or pollution of air, water, and land, and ecological law, focused on the living components of the environment $[3,18-20]$. This article examines the possibility of constructing ecological quality standards based on the provisions in the Directive, by scrutinizing the essential theoretical assumptions of the Directive and quality standards, and in the process providing an alternative interpretation of the development of ecological standards.

By illustrating the Directive's inability for achieving its objective of 'good ecological status' via quality standards, I attempt to demonstrate a general legal inability to achieve ecological objectives. Therefore, this discussion not only criticizes quality standards, but also emphasizes the approaching consequences of an 'alien' legal approach, separated from a systemic understanding of ecosystems, systems intrinsically and extrinsically connected in complex wholes.

\section{Quality Standards}

The general ecological objective for all bodies of fresh water and groundwater within the European Union is 'good status'. In detail, the Directive distinguishes surface water from groundwater; for surface water, 'good ecological status' or 'good ecological potential' is the aim, and for groundwater it is 'good status' (see Article 4 and Annex V). 'Good ecological status' is understood to refer to the quality of the structure and process (functions in the Directive) of aquatic ecosystems, a legitimate objective, since the current status of European river basins is severely damaged, and throughout Europe, common goods are dwindling, in terms of functioning ecosystem services [21-23].

As a 'mere' linguistic manifestation, the objective, with its underlying rationale and logic, may be perceived as arbitrary, but it is a legal objective, and is to be achieved by 2015 , or 2027, at the latest. Through legal objectives, legal definitions, and legal categorizations, law shapes, defines, and contributes to the creation of the real, and, as such, interacts with the evolving physical reality [24].

\subsection{Recollection and Simplification}

Quality standards may be divided into several noticeably different standards, two important ones being 'ecological quality standards' and 'environmental quality standards'. For example, environmental quality standards limit the maximum amount of a chemical that may be present in a body of water, which, in principle, is always achievable, if enforced at the point where the chemical is introduced into the body of water by human agency. Taking regulatory action to prohibit or restrict this introduction will ensure that, sooner or later, the standard is met. On the other hand, an ecological standard requires that a certain composition or abundance of particular species of flora and fauna be present in a specified part of the body of water or river basin. In contrast to environmental quality standards, this cannot be similarly guaranteed, particularly where the means of achieving it are unknown, or the reasons for failing to do so are not anthropogenic. The causality relationship 
underlying environmental quality standards and the mechanisms for their realization may not necessarily hold, insofar as ecological quality standards are concerned [3].

An environmental quality standard is a scientifically formulated and numerically expressed specification of the maximum level of contamination that is legally permissible in a given part of the physical environment. As a direct counterpart to this, an ecological quality standard should be a statement of the minimally acceptable states of ecosystems and their biological components, with a corresponding legal obligation to prohibit any deterioration below that standard. Hence, for biological communities and their habitats, ecological quality standards are intended to serve as mandatory baselines for minimal levels of diversity and abundance, specified quantitatively for each component, and backed up by legal obligations, to ensure their realization [3]. For example, with regard to different kinds of bodies of water, Annex V of the Directive stipulates that there must be an assessment of the composition and abundance of phytoplankton, aquatic flora, benthic invertebrate fauna, and fish, ecological variables linked to a non-deterioration principle, but emphasizes priority substances in the construction of quality standards [25]. Still, legal standards based on ecological variables are needed, to specify and determine what ecological status is preferable for a river basin [3].

Despite the advantages of using the abundance of particular species or habitats to measure periodic progress or deterioration when trying to conserve biodiversity, 'indicator' approaches fall short of what is required to achieve the objective of 'good ecological status' [26,27]. Monitoring biodiversity changes is a different assessment exercise than trying to secure predetermined and specified ecological objectives [3].

Quality standards are intended as norms that reflect a limit of environmental/ecological deterioration, and are connected to rules that affect the causes of a low status. The limit may be the presence/abundance of certain quality elements, with the overall aim of sustaining and maintaining either ecosystems and organisms, or certain levels of nitrogen or toxic substances, for example [9]. Through this assessment, quality standards are thought to be able to mimic the non-linearity and irreversibility found in ecosystems [3,9].

However, ecological epistemologies often proceed from a reduction of complexity in understandable subsets. Failure to recognize the limitations and unspoken assumptions of this method can lead to legal problems, risking the over-application of over-simplified concepts [28,29]. For example, the assumption that the study of nitrogen and legal enforcement will lead to a general legal model for achieving environmental or ecological objectives is not viable since, by studying nitrogen alone, it underestimates the importance of interactions, and neglects the properties of complex wholes: for example, it fails to acknowledge the inseparability of the physical environment and biotic variables, and asserts that an ecosystem is no more than the sum of its parts. Biological mechanisms, functions, or properties, in relation to organisms and systems, may not be identified with single-level reductionism, emphasizing the difference between reductionism as a deterministic and traditional method, and a holistic and legal selection of the most suitable variables for river basin assessment [30-32].

Quality standards are based on the perspective of reduction, that we may reduce the complexity of ecosystems to certain variables, and then expand the achievement of a certain concentration of that variable into the achievement of the objective of 'good ecological status'. Achieving a quality 
standard, in terms of attaining a certain presence of species, a level of nitrogen or oxygen in a body of water, is a reductionist method.

From the outset, the Directive emphasizes the importance of the river basin, with reference to the objective of 'good status' (e.g. see preamble (13) (33)), and the environmental objective in Article 4 should be formulated with reference to the river basin management plans. A river basin may be one of the more appropriate examples of the need for holism, rather than reductionism, given that its ecological status is constituted by the properties that arise from the whole of the river basin and the interconnected ecohydrological systems, and not from individual bodies of water. The ecological status of a river basin cannot be reduced to the assessment of fragmented parts, that is, for the properties to manifest; a connection between the bodies of water is necessary. The Directive, based on the integrated and holistic river basin concept, has its theoretical assumption-illogically-in traditional reductionism, without recognizing the difference between a certain quality element and the holistic objective of 'good ecological status'.

The assessment systems fail to incorporate the understanding that reductionist thinking only has truth claims at one level, which does not connect with the fulfillment of a holistic objective, such as 'good ecological status'. More acceptable is holism: that is, the denial of the possibility and strict conceptual distinction of an irreducible complexity [33].

By reducing the complexity to quality elements, indicator species, or endangered species, the standards' interaction with the holistic objective malfunctions. For a legal standard to function and achieve an environmental objective such as 'good ecological status', its variables must meet two different, ontologically based truths.

\subsection{Legal Certainty-An Ecological Perspective}

In law, there is a certain perception at work, a deep rationalism aimed at sustaining society's social expectations, this being the legal property of certainty, which affects the socio-ecological systems supporting society [34]. This legal property may, for example, create faith in a government, and provide opportunities for citizens and corporations to plan their activities, and as such, is meant to establish and stabilize social expectations [2].

As a legal property, certainty has many different aspects, which have been explored in legal research [35,36]. However, in this context, the significance of legal certainty is limited to its properties of inertia and resistance to outside changes that arise with respect to ecosystem process and structures, which may result in the maintenance of the status quo, and lock-in effects [24,37]. Therefore, this discussion is limited to the ecological consequences of allowing a certain moment in time to have a normative effect on the future.

Legal certainty allows the expectations of a single moment in time to be transposed to the future. This legal transposition of expectations may be necessary for any normativity to be established and transferred to the future $[34,38]$. However, since we continuously learn more about the irreducibility of environments and ecosystems, in a sense every past moment is based on deficient knowledge, resulting in a constant risk of over-reduction of environmental complexity [39]. Since ecosystems change constantly, and thresholds for large-scale changes are very hard to observe, the transposition and establishment of normativity are problematic [40-42]. 
Even if legal certainty does not exclude flexibility or adaptability, there is a tension between a stable and predictable social environment, on the one hand, and flexibility and adaptability, on the other [2]. This tension also emphasizes characteristic notions of environmental, ecological, and other areas of law, as decisions require constant reconsideration [2,34]. Thus, the possibility of establishing complete certainty regarding ecosystems is illusory, since one cannot predict what new information will surface, regarding the impact of our use of ecosystems. Therefore, an anticipation of future modification, towards either more rigorous or more relaxed legal provisions, should be intrinsic to any environmental regulation [38].

The Directive attempts to acknowledge the non-deterministic aspects of ecosystems via three six-year management cycles, each providing an adaptive element. However, the adaptive cycles are founded on the environmental objectives of Article 4, based on the provisions in Annex $\mathrm{V}$ that direct the assessment and management, and are not part of the adaptive element. The commission may choose to change Annex V and Article 4 in 2019 (see Article 19(2)), characterizing the Directive as inert, rather than adaptive.

In this context, legal certainty becomes the legal capacity to select one depicted part of the perceived environment, to accept this picture as the true reduction of an irreducible environment, and project it into the future, for an indefinite period of time. It is through these notions of certainty and predictability that a certain legal, alien, temporality and spatiality are imposed on the environment and projected into the future. Through this transposition of expectations and reduction of environmental complexity the importance of adjustment to change in ecological systems are underestimated, a fixed expectation of what the systems should be like fails to recognize the importance of the characteristics of place to human appreciation as well as to the survival of the systems themselves.

\subsection{Concluding Remarks}

The legal intervention of a quality standard risks causing alienation and placelessness, by assuming that ecosystems may be assessed and rehabilitated by reductionist variables, forcing ecosystems into a legally defined 'restoration' box, when the systems demand a sphere with evolutionarily defined limits characterized by ecological properties, life-history characteristics, and a propensity for change. Economically, this raises the issue of whether the regulatory approach is appropriate. For example, the Directive advocates the re-creation of environments that are similar to those of the era of early agricultural societies, an almost pre-human state, which is economically questionable. It may, perhaps, be accomplished at a local level, to represent historical-cultural and ecological states. The risk is that any further expenditure or legal force aimed at trying to reduce organic pollution, for example, will not in themselves achieve the objective of 'good ecological status' [43,44].

\section{References and Baselines-Essentiality Confused}

In historical studies, there exists the idea that objective knowledge may only be attained if there is a certain historical distance. This presupposes that the significance of some thing can first be objectively known when it belongs to a closed context; only then does it seem possible to exclude the subjective involvement of the observer. However, the attained knowledge of a historical event is never used to reconstruct the past [45], emphasizing that we belong to history; it does not belong to us [33]. 


\subsection{High Ecological Status}

The ecological aspirations of the Directive regard human activity as a source of disturbance, preventing bodies of surface water from approaching their near-pristine reference status ('good ecological status'). The Directive recommends that humans take responsibility for aquatic ecosystems, and reduce the impact of their influence, and in the preamble it is stated that, 'Water is not a commercial product like any other but, rather, a heritage to be protected, defended and treated as such'.

The baseline and reference point of the Directive is (see Annex V Section 1.2. Table 1.2.):

There are no, or only very minor, anthropogenic alterations to the values of the physico-chemical and hydromorphological quality elements for the surface water body type from those normally associated with that type under undisturbed conditions.

The values of the biological quality elements for the surface water body reflect those normally associated with that type under undisturbed conditions, and show no, or only very minor, evidence of distortion.

These are the type-specific conditions and communities.

In general, this is defined as an ideal reference point, since it is a historical, pre-human state of ecosystems, a nonexistent state today, a state unknown [46]. This ideal picture of nature, painted by the Directive, is its baseline. The normative effect of 'high ecological status', with reference to 'good ecological status', is created with reference to Article 2 (21), Article 2 (22), Article 7, Annex II 1.3, and Annex V 1.2. This is the baseline upon which the general obligations of the Directive are based, including the non-deterioration provision (see Articles 1 and 4). This baseline is consistent with the assumption that those environmental conditions that prevailed prior to the industrial period, or even those that prevail in the contemporary environment, represent a somewhat natural state, and are thus something that should be preserved or restored [47].

However, ecosystems are non-deterministic, continually change, react to present disturbances, and also those from the past, perhaps even unknown ones, and degenerate because of intrinsic ecosystem processes $[15,48]$. Furthermore, for a long time, human influence has been extensive in all regions of the world with a long history of agriculture and industrial activity, such as Europe, and many of the natural and anthropogenic changes occurred over decades or centuries, making it difficult for individual human beings to observe the changes, and distinguish them from non-anthropogenic changes [47,49].

The Directive mentions another (if not final) alternative for establishing an appropriate baseline for river basins and bodies of water: paleoecological records (Annex II 1.3. (v)). Such records may provide a longer temporal perspective relating to the determination of natural variability and the construction of baselines. For example, paleoecological data may be used to determine the possibility of enforcing measures to reduce non-point-source organic pollution in a lake, thereby returning the body of water to an pre-eutrophic state [50].

As an example, the eutrophic Swedish lake, Nedre Milbodsjön, is targeted to achieve 'good ecological status' by 2015. It is evident that the status of the body of water is the result of human influence, non-point organic pollution; for reference, most nearby lakes are oligotrophic. To achieve 'good ecological status' and deviate only slightly from a body of water normally associated with a 
type-specific, 'high ecological status' body of water, and return the body of water to somewhat pre-agricultural conditions would require the exclusion of all agricultural activity from the area, or decoupling the lake from the river basin, to manage and reduce the significant historical and current impacts of organic pollution [47]. Instead of using paleoecological data to create appropriate baselines for the Directive, the paleoecological records unfold ideas of 'naturalness' or 'unnatural states', emphasizing how ecological and human-induced change are natural parts of our world [51,52]. Thus, paleoecological records provide a historical idea of past ecological states, the changes wrought, a possible idea of the history of the system.

Some may argue that expert judgments would be appropriate for establishing baselines (see Annex II 1.3. (iii), Annex V 1.3.4., Annex V 1.4.1. (v)) [53]. Expert judgment has been criticized, since it may be biased by personal field experience and anecdotal information, and it appears difficult to distinguish human pressures from natural variability [54]. Each generation tends to set its own reference state, employing the information from the period believed to be most relevant, and perceptions of what constitutes 'good' may decrease, as the public and experts become accustomed to a lower ecological status [55].

There it is nothing particularly natural or self-evident about any ecological baseline. For example, establishing an 'appropriate' baseline involves judgments that are guided by values or proto-norms; norms that lie somewhere between written rules and unwritten values, such as policies or principles, that remain in close contact with the background reasons existing in some parts of society. These proto-norms are situated at the conceptual edge or boundary of legal and pre-legal discourse formation, and must be acknowledged, as they affect decisions concerning the kind of environment that will be created, if the objectives are achieved [36,56-58].

It is important to realize that humans have affected and reshaped nature for thousands of years, and the current state of the landscape is largely a product of human influence. Humans are part of both local and global ecosystems, and one of the many agents for environmental change.

\subsection{Maximum Ecological Potential}

The problem with establishing appropriate baselines for achieving ecological objectives and further legal obligations becomes even more apparent for 'heavily modified' or 'artificial' bodies of water, which are only expected to achieve 'good ecological potential' (see Article 2 (23), Article 4 (1)(a)(iii)). These bodies of water have been constructed or significantly altered by humans. In a regulated river, a common example of a body of water defined as 'heavily modified' or 'artificial' is a reservoir, constructed by establishing dams and hydropower stations. In Sweden, most rivers defined as 'heavily modified' are essentially staircases of lakes and reservoirs, linked by fragmented stretches of river with hydropower stations.

The baseline for these bodies of water is (see Annex V 1.2.5.):

The values of the relevant biological quality elements reflect, as far as possible, those associated with the closest comparable surface water body type, given the physical conditions which result from the artificial or heavily modified characteristics of the water body. 
The hydromorphological conditions are consistent with the only impacts on the surface water body being those resulting from the artificial or heavily modified characteristics of the water body, once all mitigation measures have been taken to ensure the best approximation to ecological continuum, in particular with respect to migration of fauna and appropriate spawning and breeding grounds.

Physico-chemical elements correspond totally or nearly totally to the undisturbed conditions associated with the surface water body type most closely comparable to the artificial or heavily modified body concerned.

Nutrient concentrations remain within the range normally associated with such undisturbed conditions.

The levels of temperature, oxygen balance and $\mathrm{pH}$ are consistent with the those found in the most closely comparable surface water body types, under undisturbed conditions.

To summarize, the baseline may be interpreted by studying the closest comparable type of body of surface water, with the only impact permitted being that resulting from the artificial or heavily modified characteristics of the body of water; in general, the body of water should resemble those with nearly undisturbed conditions.

Some, perhaps even most, of these bodies of water were constructed or made artificial over the centuries. For example, the Swedish world heritage site and National Park, 'Stora Sjöfallet', established to preserve Nordic mountain scenery in its natural state, will soon be celebrating its 100th anniversary as a protected reservoir, including the adjacent mountains, built to generate hydroelectricity (second largest in Sweden, with regulation amplitude of 30 metres). Among reservoirs, those built for generating electricity usually have the most pronounced fluctuations in water level, so that even flow patterns, temperature, dissolved gases, and concentrations of waterborne material are also highly affected. Furthermore, the abundance of both aquatic vegetation and fauna depend on the range of water level fluctuations [59].

Hypothetically, if a reservoir is to be returned to a more 'natural' state, the improvement in the ecological status would involve assessment over decades, which exceeds the timeframe of the Directive. Furthermore, ecosystems may not be able to functionally recover, if the legacy of the damage is irreversible, or because other river basin changes restrict the rehabilitation [60]. The necessary timeframe for these kinds of rehabilitative actions would exceed both the timeframe of the Directive and the lifetime of a single human being, risking 'shifting baseline syndrome': that is, the public or governmental agencies might be unable to contextualize the rehabilitation, and might not perceive the changes as recovery or regression [58,61]. For manmade landscapes, pristine, natural baselines are inappropriate, and, as outlined in Annex $\mathrm{V}$, the objective becomes unachievable, and would probably not lead to an overall improvement in ecological status for the river basins involved [60].

The problems associated with ecological potential have been somewhat acknowledged by the implementation process. The objectives for these bodies of water are generally based on the Prague or mitigation measures method, and only some member states refer to type-specific conditions actually found in ecosystems. This has resulted in situations where, if a body of water supplies a specific 
function that also prevents the attainment of 'good ecological status', this may be used as an excuse to do nothing, owing to policy discretion, even if mitigation measures are mandated to attain the objective [62,63].

The problematic aspects of both theory and implementation highlight the need to establish baselines founded on the remaining ecosystem potential. Practically, this means an ongoing justification of any legally established activity relating to the river basin, and exploring the possibility of removing a significant number of permitted and pre-permit activities, and then allowing for new permitted or planned activities to exploit the natural resources, based on an ecological assessment at river basin scale. Activities must be put into their correct ecological and cultural spatial and temporal context, for example, the implications of an activity are not predominantly explicit for one or a few bodies of water but the entire river basin.

The legal vision of establishing functional baselines that reference the pristine is questionable, for ordinary surface water, and is unfounded for human-created bodies of water. The importance of place is missing within such a vision, and demonstrates the inadequacy of any general 'solution' or provision.

If the Directive is amended in 2019, Member states should not be required to distinguish between natural, 'heavily modified', or 'artificial' bodies of water (Article 8, 9). Instead, current ecological, human, and cultural realities must be confronted.

\subsection{Concluding Remarks}

The Directive is intended to establish baselines of normative attraction, based on an intrinsic system assessment focused on a pre-human world, instead of facing ecological realities and their propensity for change. It almost seems as though the Directive and Annex V were designed to be reliable enough to handle the uncertainties of reality and science, a transdisciplinary construction handling all expectations, and aiming for absolute knowledge and complete certainty.

The criticism of both the Directive and quality standards is to some extent directed at their underlying theoretical assumptions, established on the basis of the idea of complete certainty. The Directive finds certainty in its reference to, and aim of restoring near-pristine, untouched ecosystems, and in quality standards, through the over-reduction of complexity into quality elements. Both have their bases for certainty in an internalization of certain outdated scientific findings supporting the legal misconception of control over natural resources.

The assumptions underlying the Directive assume that society can mitigate ecosystem damage through the restoration of degraded areas, and by the creation of new habitats to increase physical heterogeneity within the river basin. These assumptions have been described as a myth rooted in early 19th century ecology, based on the idea that ecosystems develop in a predictable fashion towards a specified status, end point, or climax $[28,48,64]$. For example, isolated restorations that disregard the interconnectedness of river basins do not necessarily result in 'good ecological status' [65]. Because of its 'objectivity', this end state may seem attractive to the environmental legal system, a precise state towards which to progress. However, there is no basis for assuming that the achievement of a pre-established target condition is possible, it is one of many, many possibilities in a world of propensities. A more profitable approach is to create a system corresponding to the inherent processes 
and structures, and not the complexity of an irreducible environment [66,67]. The use of historical conditions as references for establishing baselines is evidently possible, but not without emphasizing the ontological truth claim arising from such historical operations, and questioning the meaningfulness of it.

Where the assumptions underpinning the Directive go astray is in overlooking the simple, and perhaps useful, difference between an operational legal actor, and nature as an inert and rigid observer that only reacts to the operations of the actor [68]. Behind nature as a passive onlooker stand generations of human beings who, both intentionally and unintentionally, have changed the fundamental evolutionary and ecological adaptations that constitute the environment as we know it, converging ecological and evolutionary time scales [69]. The actors have created, and continue to create, an environment coupled to these actors. Behind nature stand human beings creating a coupled path dependence between themselves and the environment, at a sub-level between the legal system and the ecosystems.

The environment is a multi-layered construction based on generations of humans interacting with ecosystems, a diverse mixture, interconnected with, and overlapping the contemporary landscape [70-72]. Today's poor ecological statuses describe more or less irretrievably modified ecosystems. The pristine state that established the type-specific reference point is constructed on a fiction that society can reconstruct the starting point of our cultural evolution. This reference point seems founded on social expectations and intellectual speculations (expert judgments) about to some pre-human past, which are deemed superior to the present ones. Outside of the legal system, nature or a pristine system appropriate for assessment no longer exists. However, within the system, there is an external reference to an environment that is not representative of what exists outside the system [34].

Still, some argue that pristine baselines may be found, and are found in remote places in the world [73]. Hypothetically, if a pristine reference is found, it must be built on a priori reasoning, resulting in a classification system similar to the systems that, up to now, have failed to acknowledge site-specific preferences, and instead impose uniformity across the landscape resulting in placelessness and loss of diversity [16,66]. A preferable approach, for all bodies of water, is to implement assessment systems that are site-specific, that do not lose sight of the importance of place and time, and see the importance of the unique cultural and ecological reality of every river basin, assessing the history that is meaningful for that society [74,75]. Instead of being perceived as a disturbance, human activity should be understood as a fundamental trend, affecting nature at all levels [76]. In the twenty-first century, nature is what we make of it, that is, the heritage left us by previous generations [70,77]. The environment is ecological, human, cultural, and perforated [34].

The directional trend towards placelessness and alienation established by the Directive is recognized as an awkward part of modern positivist law. For example, legal baselines or references have not only been situated in a pre-existing environment (pristine reference point) but also in entirely different environments (applying legal systems adapted to a set of ecological conditions to other, different ecosystems), and in idealized environments (ecological sustainability), all of which produce an inadequate relationship between laws, places, and the things regulated [17].

More acceptable would be a focus on organisms' life histories, and how they transcend legal classification; whenever and wherever human interest follows these mobile forces, they create a public arena in the midst of legal provisions [78]. 


\section{Quality—Essential?}

The incredible complexity of nature forces us to simplify the systems of study. Still, complexity must be accepted, and uncertainty cannot be neglected. Axiomatically, this means that ecosystems will always be more complex than any assessment or management system. Therefore, the legal system must be selective, when reducing this complexity. Through selectivity, the legal system addresses the ecosystems' complexity, and reduces it to a manageable, legal-system complexity, differentiating the legal assessment system from the ecosystems, but also establishing a coupled, systemic path dependence between the systems [34].

Applying selectivity it is crucial to perceiving the difference between selecting an array of suitable variables, and reductionism as a traditional scientific method aimed at determining what is non-deterministic, or, accepting holism without acknowledging the legal requirement of measurable variables. Since ecological structures and processes, such as water flow, are the main evolutionary and ecological factors that determine the ecological status of an entire river basin, variables for ecological standards must integrate both holism and reductionism, and surpass them both.

\subsection{Water Quality}

Water quality is traditionally interpreted as the set of physical/chemical properties of water. The legal approach to controlling harmful activities and the use of natural resources was developed for coping with domestic environmental and health concerns, through a traditional, reductionist approach $[2,76]$. For example, water quality in bodies of water affected by agriculture was assessed by measuring dissolved oxygen, biological oxygen demand, and ammonium concentrations, each being an indicator of organic pollution. Later, macroinvertebrate communities were assessed and scored on a scale that reflects the susceptibility of particular groups to organic pollution and deoxygenation [80]. This kind of regulation has succeeded in restricting some damaging activities. However, the continuing deterioration of the ecological status of river basins in Europe has not been halted [23].

The Directive was supposed to change this, and it specifies that bodies of water in the Union should be managed on a river basin scale (e.g. see Annex VII). When the EU Community adopted Annex V of the Directive, the Community presupposed that a methodology for assessing ecological water quality (with reference to the achievement of the holistic ecological objective) was possible, and would be sufficiently rigorous to allow for a normative state to be stipulated by law [3].

Annex $\mathrm{V}$ is based on the idea of using quality elements to achieve the objective of 'good ecological status', and is based on an assessment that derives elements from a pristine state (see Annex V 1.2. Table 1.2.). The legal assessment reduces ecosystem complexity to a few quality elements, defines an appropriate number of the elements, and uses a legal standard to implement measures to reduce or increase the quality elements. When implying that reversing a quality element to a certain statistical value in relation to a static historical reference point, and further stating the fulfillment of a legal objective, the enforcement becomes biased towards a linear view, aimed at reversibility.

The advantage of this approach is that by directing a standard at some given, for example, toxic compounds, or oxygen or nitrogen levels, the approach may be applied to almost all bodies of water. However, levels of sedimentation, nutrients, and other variables that are linked to ecosystem status 
vary within and among bodies of water, rivers, and river basins [16]. At this point, the advantage becomes a disadvantage, as the assessment system risks treating diverse, dynamic, and complex ecosystems as though they were identical, reducing the potential found in ecosystem services, for example [16,81]. This assessment process neglects all the ecological factors in a river basin that will not change, notably, the presence of non-native species $[28,82]$.

Instead of directing the assessment at the whole river basin, a flawed framework for assessment was constructed within Annex V, and the Directive is built on the simple environmental determinism of the mid-twentieth century, thereby defining the achievement of 'good ecological status' as a particular set of concentrations of substances, a prescribed list of species, or an agreed-upon list of habitat features, without actually assessing the ecological status [22,26,27].

Believing that it is possible to achieve 'good ecological status' by increasing the level of a quality element derived from a pristine-state reference point, or by enforcing a quality standard or some other legal tool is overly simplistic, reflecting the human tendency to rely on partial truths and assumptions when pursuing objectives aimed at ecological rehabilitation, instead of facing the irreducibility of every environment.

By the use of ideal references, quality standards are constructed in line with the Newtonian idea that, once the initial conditions are known, you may calculate all subsequent states, as well as the preceding ones, along a linear scale that may be based on a set of concentrations of various elements, such as nitrogen or oxygen, or a list of species or habitats that have been defined by a simple ecological quality ratio or index (termed EQI, see Annex V section 1.4.1(ii)) [22,76].

The approach of using the presence, absence, or concentration of quality elements may be reasonable, when trying to improve and create a homogeneous environment in a city, in terms of reducing harmful substances in water or air, for example. Using the same legal design to assess the status of ecosystems reduces the measurable information available to variables or qualities that have little or no capacity to express the actual status of the river basin. An ecological status or a defined limit based on the presence, absence, or concentration of quality elements may neither improve nor rehabilitate the systems of the river basin, as no substantial indicative information is provided by the fact that, for example, a species (endangered or not) is scarce, or a certain level of nitrogen or oxygen is measured at a potentially affected site, and compared to that of a reference site.

Part of the problem with indicator species originates in the fact that large numbers of species have never been catalogued, and baseline population statuses rarely exist, with the exception of a few, threatened species, or species with commercial value [83]. There may be many reasons for assessing and protecting endangered species, but the assessment of the ecological status of a river basin is not one.

By the use of 'quality elements', assessment addresses an over-simplified and over-reduced feature of ecosystems, and from this, generalizes about the entire environment, connecting a certain quality level to the objective of 'good ecological status', without perceiving the ontological difference between a level of reduced quality and a holistic legal objective. Regardless of whether (or not) comprehensive scientific reduction will eventually prove possible in the future, it is certainly not possible today.

This irrationality is observable in the Directive. At first glance, it seems to be directed at river basin management. However, by using certain quality elements or an agreed-upon list of habitats to divide 
the basins into individual, uniform bodies of water, or for that matter, into the heavily affected and artificial, versus the natural, the assessment, through reduction, fragments, instead of connecting the bodies of water, in an assessment aimed at interconnected, adaptive water management (cf. Article 5, Annex II 1.). The results seem to be case-by-case management plans for individual bodies of water, regardless of their potential to provide highly valued habitats with respect to the entire basin, thereby overlooking the fact that poor habitats with low status may occur naturally, and be valuable on a river basin scale, owing to life-history patterns [16,22].

The definitions and underlying rationale and logic supporting the Directive reinforce the approach of reduction and restoration, without considering the environment that surrounds it, and that it creates, through its interventions. Problematic on its own, the Directive's normative structure is also at work in a historical landscape where humans have simplified and created 'stable' ecosystems, and already reduced their ability to reliably supply services [84].

The Directive has established an approach that attempts to re-create a complex system from simplified variables, without recognizing the inherent over-simplification and over-application. As results, the ecosystems, in their irreducible complexity, remain all too absent from the legal system, simply because of old-fashioned, ecological reduction.

This discussion is closely related to the meaning of time, and accepting that past and future do not play symmetrical roles, meaning that variables that incline to a linear and symmetrical view also incline to determinism and the reversibility of time [76]. The legal objective of 'good ecological status' and the legal instrument quality standards become, by design, aimed at reversing time and irreversible change.

\subsection{Concluding Remarks}

Instead of properly considering contemporary knowledge, the Directive was constructed on a flawed understanding of ecology. The failure to recognize the limitations and tacit assumptions underlying the ecological epistemologies used will probably lead to an over-application of over-simplified concepts to complex systems for decades to come. If the assessment system is not reformed, it cannot assess the fundamental properties of river basins, and probably cannot 'see' the ecological distress affecting the fundamental structures supporting the ecological systems of a river basin, possibly resulting in a reduction in diversity.

The normative structure established by the Water Framework Directive seems to be moving society and law along a path towards increasing alienation and placelessness, and risks becoming a part of the problem it was supposed to address. Also absent is the essential fact that diversity has meaning, and an inefficient, unenforceable, or even impossible, path towards the objective of 'good ecological status' has been created.

When trying to ecologically rehabilitate the statuses of ecosystems, complexity must be recognized, because it is possible to reduce the complexity of ecosystems without losing the causal relationship between the different scales leading to large-scale, holistic assessments, by emphasizing life-history characteristics of river basins. Complexity and holism are addressed by connecting the objective of 'good ecological status' with life-history characteristics and normative legal instruments that relate the status of a body of water with river basin properties. A life-history approach would acknowledge the 
importance of stress and habitat disturbance as the main evolutionary and ecological factors, placing the assessment within the spatial scale of the river basin, and the temporal scale of evolutionary and ecological timeframes.

\section{Temporality}

For a long time (some argue, for 5000 years), the legal system has interacted with the environment, and through legal certainty and predictability, projected the consequences of these interventions into the future [85]. Through these interventions, the legal and ecological systems became coupled with, and dependent on, each other; they became followers of history, and part of the flow of accidents and events leading up to today, and into the future.

It is noticeable that law defends old interests, and has done so from its earliest beginnings, and only through struggle can new interests emerge and receive the recognition of law [33]. In this way, the 'new' environmental law discourse began, through the growing number of environmental problems, the convention of biological diversity, and the Brundtland report, often in conflict with established knowledge of law $[86,87]$. The Directive may be perceived as an achievement of the environmental legal system. It presents lofty ecological ambitions, it is the first Directive drafted through governance, conceptualizing a shift towards more participatory and soft law approaches, emphasizing targets and not means, and it is functionally oriented towards sustainable development $[29,88,89]$. Temporally, this emphasizes internalization and an acknowledgement of future generations.

Even if the future is the main focus of the Directive, the past and present are also significantly present. For example, an enforcement decision directed at the future is made in the present by applying the predetermined past of Annex V. As discussed above, such historical operations, aimed at restoration, are unworkable. Apart from the irrationality of the Directive, we are left with the realistic projection of some parts of the present directed towards an undetermined future, trying to acknowledge the generations to come, accepting that time cannot be regained. History and past are thus differentiated by the logic of the present; the future becomes the selected parts of the past that create the expectations and selected history of the present, differentiating the present from both the past and the future [90]. Still, temporal problems will appear, if expectations are misleading, owing to idealized historical descriptions, and run counter to legal, social, and ecological experiences.

\subsection{Temporal Problems}

In this context, three concepts of time (frame) are relevant: ecological (chronological or natural) time, lived time, and legal time. Both lived and legal time create their own temporalities, even if they may coexist and be interrelated, sometimes oblivious of ecological time, allowing alienation and placelessness to become established [17,33,90,91].

Traditional, positivist legal theory is based on a specific conception of time: time as socially shared, homogeneous 'objective' time, or as lived, experienced, time often considered as subjective. Time in Newtonian theory is a homogeneous quantity, an ahistorical entity that may be repeated and counted, a conceptualization used in legal theory. Time as a legal object may be grasped definitively, time is a linear, dynamic sequence of events, and the legal system is neutral in its assessment of it, and does not depend on the specific forms of life assessed. The future is predictable $[91,92]$. 
The legal timeframe for achieving 'good status' for fresh water and groundwater is determined to be 15 years (2015) or, with exceptions, 21 or 27 years (2021 or 2027) (see Article 4 ((1)(a)(ii), (4)(c)). However, the recovery of a river basin takes many years, and more probably, decades, requiring long monitoring programs over relatively extensive areas, to evaluate progress or regress [93,94]. The Directive's timeframe' emerges as a normative order regulating the river basins towards its legal objective, within its legal timeframe, in conflict with ecological time.

A realistic and more appropriate ecological timeframe for river basin rehabilitation would be around 100 years. Such a time interval would facilitate the measurement of the necessary and substantial changes that occur within a river basin. It would also represent 20 to 50 salmon generations, for example, and thereby enable the measurement of both ecological adaptations and evolutionary changes [81]. Atlantic salmon, for example, have a relatively narrow environmental tolerance, and have specific habitat requirements at each life stage; they are sensitive to the conditions of the entire river basin. The response diversity (variation in response to environmental change among species within the same ecosystem) of salmon populations springs from the habitat opportunities of the whole river basin $[95,96]$.

There are studies showing life-history adaptations within 14 salmon generations, possibly reducing the necessary ecological timeframe. However, riparian trees demand at least 30 to 40 years to develop, and streams and riparian processes and structures depend on large trees, up to a century old, to provide wood to structure the channel; finally, recovery following a dam removal may take up to a century, although monitoring rarely exceeds 5 years, leaving the timeframe for recovery after dam removal speculative, in the absence of monitoring data that covers multiple decades the assessment of multiple life-histories over the range of several decades up to a century seems reasonable, incorporating unpredicted progress and regress. [48,84,97-99].

This emphasizes the importance of encompassing the entire life history of species (their ecological timeframes) when rehabilitating a river basin (e.g. both demographic structures and physiological responses) [100]. The life history of species bring attention to the temporality of habitat conditions and how this transient state differs from the objective of 'good ecological status' as a single objective for all bodies of water [101].

A planning horizon of 100 years would be long enough to allow natural disturbances and other ecological processes to provide a genuine increase in the overall water basin productivity, and therefore also an observable ecological status change, allowing for an assessment that emphasizes the processes and structures that maintain and diminish diversity [16,21,22,78]. With this time horizon for assessment and management, there would be a focus on scales generally neglected, such as the range of multiple decades [84]. This would also force the assessment to evaluate the probable outcome of current global changes, such as climate change.

One fundamental assumption that underlies a target-oriented legal instrument is that a properly staffed and regulatory body with adequate resources is able to exercise its management powers, to ensure that the objective is actually met within the specified timeframe [44]. However, expecting complete recovery in the span of a single human existence, or lived time, is unreasonable, even when there is potential for a full rehabilitation. For some time, ecologists have used the concept of 'shifting baseline syndrome' to describe a slide in standards, such as legal baselines for ecosystem status, owing to a lack of experience, and ignorance of the historical conditions [102]. The risk with longer 
timeframes (e.g. 100 years) is generational amnesia, where knowledge extinction occurs because younger generations are unaware of past biological conditions, resulting in a conflict between individual memory, collective memory, and the historical memory [58,103].

Even if the ecological time span of 100 years may seem risky with reference to lived time, within law, a legal timeframe of 100 years is not that uncommon, when trying to manage protected areas (Nature-2000) in Sweden. A railway was allowed to pass through a Nature-2000 site, a wetland; the location was disputed and subjected to several juridical reviews. The wetland is valuable to migrating birds that rest there during the spring and autumn. As a long-term compensatory measure to ensure a functional Nature-2000 site, a water permit was issued to establish dams and pump structures, to create the necessary seasonal water fluctuations of a compensatory wetland. In Sweden, water permits are subject to review, but in reality are seldom or never reviewed, making the permits 'eternal', creating an ecological lock-in effect by establishing compensatory measures that are not adapted to the ongoing ecosystem changes, most noticeably changes in the natural elevation of the land in this area of northern Sweden [47,104-106].

From a legal standpoint, a century emphasizes a temporal agreement and a normative commitment to acknowledge the generations to come, emphasizing social change within a reasonable timeframe that both stabilizes and destabilizes the expectations of the present.

\subsection{Concluding Remarks}

The Directive, constructed on a flawed understanding of ecological time, gives EU Member states an insufficient timeframe for rehabilitating what will probably require decades or, more probably, centuries. The legal expectations (timeframe) differentiate themselves from the lived and ecological timeframes.

A legal spatiality is established on the basis of a selective historical description, established by idealized ecological epistemologies, implying that certain knowledge also has been rejected, an effective forgetting of history, transposed into the future. There is a risk that a legal projection of this normative pattern will create environments poorly equipped to handle the ongoing presence of humans.

If legal time and ecological time are inconsistent, a temporal problem appears. Is it possible to achieve the objective of 'good ecological status' within the timeframe of the Directive? Or, is the Directive merely an ideal, packed with powerless rules and provisions, incapable of achieving what it deems most important? To some extent, Article 4(4)(c) is the legal time saver, since it allows for an extension of the necessary measures over an indefinite time period, if the natural conditions are such that the objective cannot be achieved within the predetermined legal timeframe.

This legal situation emphasizes the uniqueness of the environmental legal system, and, with reference to ecological exclusivity, it would be appropriate to start characterizing the environmental legal system, not by its ability to fix expectations temporally, but by its inability to do so. This is simply an attribute of the environmental legal system, owing to the irreducible complexity of the environment [34]. The legitimacy of the environmental legal system is founded on the ability to acknowledge the intrinsic irreducibility of social and ecological systems. 


\section{Visualizing Consequences}

Twenty-seven years is long time for a human being, but not very long for ecological systems, in terms of rehabilitation. However, 27 years is long enough to cause damage to ecosystems by creating an 'alien' assessment and management state. With this short legal timeframe, there is also the risk of favoring small and rapid ecosystem processes, capable of delivering ecosystem services on an immediate, local scale. This often leads to the misperception that managing small/fast processes is sufficient, when managing ecosystems, making it difficult to consider and advocate for the importance of broader and slower processes [107].

The difficulty in assessing and comparing large-scale processes and structures with small-scale options echoes the already-discussed conflict between reductionist and holistic assessments. The two issues may be entwined in the phenomena of cumulative impact and nonlinear trajectories, since both are sensitive to initial assessment, actions taken, long-term conditions, and the effects of the aggregation of events in small/fast scale domains, resulting in bridged thresholds for both small- and large-scale domains [107].

Contemporary aquatic environmental problems may not be addressed by either reductionist variables or small-scale processes or structures, but through an assessment founded at several spatial levels and temporal scales, from river basin to body of water, an assessment system emphasizing the unique cultural and ecological realities existing in every river basin. If assessment and management plans are constructed without this understanding, there is the risk of established baselines and references becoming unsound. By overlooking the cultural and ecological importance of place, the ecological structure in the Directive constrains a broader notion of rehabilitation and restoration, and follows the traditional and current practice of the natural sciences in applying a reductionist approach, instead of a holistic one, as in the tradition of humanistic methods [74,108].

Failure to recognize the limitations and tacit assumptions of ecological epistemologies may lead to environments poorly equipped to handle the ongoing presence of humans, since it will lead to the over-application of over-simplified concepts to complex ecosystems, reducing diversity, by treating diverse, dynamic, and complex ecosystems as though they were identical $[16,109]$. This may have unintended ecological effects, such as decreased long-term productivity. Meanwhile, the Member states are obligated to promote a placeless universalism, and risk creating a homogeneous environment of diverse and dynamic ecosystems, hindering the capacity of future generations to address these concerns $[16,50,81,101,110,111]$. At the same time, the fundamental processes and structures that establish the ecosystem services on which society depends continue to deteriorate in the EU and elsewhere [23].

\section{Conclusion}

By internalizing certain scientific findings, the Directive creates a spatial and temporal legal state poorly adapted to managing the environment it aims to restore. The epistemologies underlying the Directive and quality standards aver that comprehensive scientific reduction exists, which is not the case. 
Faced with a deteriorating world, the Directive was created, with the ideas of restoration and the pristine as its two cornerstones. The quality standards derived from the Directive may have stable variables, but are unable to adapt to change, and are incapable of achieving the legal objective of 'good ecological status'. The Directive does not address the problems; instead, it becomes part of the problem.

Ecological standards must be based on the fact that (1) human perceptions influence the establishment of legal baselines, (2) large/slow ecosystem dynamics must be combined with those that are small/fast, (3) humans and ecosystems form a systemic unity, (4) baselines shift as we move along the continua of time and place, (5) absolute scientific or legal certainty cannot be attained, (6) site-specific reference conditions are superior to type-specific ones, (7) timeframes for river basin rehabilitation exceed the human lifespan (e.g. 100 years), (8) there is an ontological divergence between the assessment of a specific quality and the general ecological status of a river basin. Thus, the variables must meet two different, ontologically based truths, in a sense transcending them both.

It is well known that industrial activity may require permits and preventative measures, and if the legal system is not adept at its task, unnecessary, harmful substances may be released into the ecosystem, degrading the services provided. However, the same care must be put into the remedial processes and structures established by law, in order to improve ecological status.

Instead of establishing an epistemic knowledge system based on reduction of meaning, a more common, interdisciplinary, system of meaning is needed, where epistemic uncertainty is restrained by acknowledging ecological and legal systems' irreducibility. The maladapted Directive underscores the need to accept that, with regard to the environment, there can never be absolute knowledge or complete certainty. It is necessary to accept that only limited truths exist, rather than to try to establish absolute knowledge and certainty based on reduction.

The legal system, characterized by self-reinforcing states of attraction, has a fundamental role to play in the rehabilitation of river basins, but may also become problematic, when previously resilient ecosystems deteriorate, and no more than the status quo is protected [112].

In the absence of reform, it is fitting to question whether any social expectations may be attached to the legal objective of 'good ecological status'.

\section{References and Notes}

1. Popper, K. A World of Propensities; Thoemmes: Bristol, UK, 1990.

2. Ebbesson, J. The rule of law in governance of complex socio-ecological changes. Global Environ. Chang. 2010, 20, 414-422.

3. Howarth, W. The progression towards ecological quality standards. J. Environ. Law 2006, 18, 3-35.

4. Directive of the European Parliament and of the Council (EC) 60/2000 establishing a framework for Community action in the field of water policy [2000] OJ L327/1 (Water Framework Directive).

5. Kaika, M.; Page, B. The EU Water framework directive: part 1. European policy-making and the changing topography of lobbying. Eur. Environ. 2003, 13, 314-327. 
6. Commission Report from the Commission to the European Parliament and the Council in accordance with Article 18.3 of the Water Framework Directive 2000/60/EC on programmes for monitoring of water status.

7. Kallis, G.; Butler, D. The EU Water framework directive: Measures and implications. Water Policy 2001, 3, 125-142.

8. Canelas de Castro, P. European Community Water Policy. In The Evolution of the Law and Politics of Water; Dellapenna, J., Gupta, J., Eds.; Springer: Amsterdam, Netherlands, 2009.

9. Gipperth, L. Miljökvalitetsnormer: en rättsvetenskaplig studie $i$ regelteknik för operationalisering av miljömål; Uppsala University: Uppsala, Sweden, 1999.

10. Krämer, L. EC Environmental Law; Sweet \& Maxwell: London, UK, 2007.

11. Westerlund, S. En Generisk Miljölag ver. 013.; IMIR: Åmyra, Sweden, 2009.

12. Sadeleer, N. de. Environmental Principles: From Political Slogans to Legal Rules; Oxford University Press: Oxford, UK, 2002.

13. Jans, J.; Vedder, H. European Environmental Law; Europa Law Publishing: Groningen, Netherlands, 2008.

14. Aubin, D.; Varone, F. The evolution of European water policy: Towards Integrated resource management at EU level. In The Evolution of National Water Regimes in Europe: Transitions in Water Rights and Water Policies; Kuks, S., Kissling-Näf, I., Eds.; Kluwer Academic: Dordrecht, Netherlands, 2005.

15. Jørgensen, S.E. Integration of Ecosystem Theories: A Pattern; Kluwer Academic Publishers: Dordrecht, Netherlands, 2002.

16. Poole, G.; Dunham, J.; Keenan, D.; Sauter, S.; Mebane, C.; Essig, D.; Hicks, M.; Sturdevant, D.; Materna, E.; Spalding, S.; Risley, J.; Deppman, M.; McCullough, T.; Lockwood, C. The case for regime-based water quality standards. Bioscience 2004, 54, 154-161.

17. Graham, N. Lawscape: Property, Environment, Law; Routledge-Cavendish: Abingdon, UK, 2010.

18. Law and Ecology: New Environmental Foundations, 1st ed.; Philippopoulos-Mihalopoulos, A., Ed.; Routledge: Abingdon, UK, 2011.

19. Brooks, R.; Jones, R.; Virginia, R. Law and Ecology: The Rise of the Ecosystem Regime; Ashgate: Aldershot, UK, 2002.

20. Westerlund, S. Rätt och riktig rättsvetenskap. Nordic Environ. Law J. 2010, 1, 3-22.

21. Norberg, J.; Wilson, J.; Walker, B.; Ostrom, E. Diversity and Resilience of Social-Ecological Systems. In Complexity Theory for a Sustainable Future; Norberg, J., Cumming, G.S., Eds.; Columbia University Press: New York, NY, USA, 2008; pp. 70-71.

22. Josefsson, H.; Baaner, L. The Water framework directive-A directive for the twenty-first century? J. Environ. Law 2011, 23, 463-486.

23. Harrison, P.; Vandewalle, M.; Sykes, M.; Berry, P.; Bugter, R.; de Bello, F.; Feld, C.; Grandin, U.; Harrington, R.; Haslett, J.; Jongman, R.; Luck, G.; da Silva, P.M.; Moora, M.; Settele, J.; Sousa, J. P.; Zobel, M. Identifying and prioritising services in European terrestrial and freshwater ecosystems. Biodivers. Conserv. 19, 2791-2821.

24. Viljanen, M. Law and ontological politics. NOFO 2009, 6, 5-18. 
25. Directive 2008/105/EC of the European Parliament and of the Council of 16 December 2008 on environmental quality standards in the field of water policy, amending and subsequently repealing Council Directives 82/176/EEC, 83/513/EEC, 84/156/EEC, 84/491/EEC, 86/280/EEC and amending Directive 2000/60/EC of the European Parliament and of the Council.

26. Moss, B. Shallow lakes, the Water Framework Directive and life. What should it all be about? Hydrobiologia 2007, 584, 381-394.

27. Moss, B. The Water framework directive: Total environment or political compromise? Sci. Total. Environ. 2008, 400, 32-41.

28. Hilderbrand, R.; Watts, A.; Randle, A. The myths of restoration ecology. Ecol. Soc. 2005, 10, Art 19.

29. Steyaert, P.; Ollivier, G. The European Water Framework Directive: How ecological assumptions frame technical and social change. Ecol. Soc. 2007, 12, Art. 25.

30. Levins, R.; Lewontin, R. Dialectics and reductionism in ecology. Synthese 1980, 43, 47-78.

31. Brandon, R. Concepts and Methods in Evolutionary Biology; Cambridge University Press: New York, NY, USA, 1995.

32. Korfiatis, K.; Stamou, G. Habitat templets and the changing worldview of ecology. Biol. Philos. 1999, 14, 375-393.

33. Tontti, J. Right and Prejudice: Prolegomena to a Hermeneutical Philosophy of Law; Ashgate: Aldershot, UK, 2004.

34. Philippopoulos-Mihalopoulos, A. Absent Environments: Theorising Environmental Law and the City, 1st ed.; Routledge-Cavendish: Abingdon, UK, 2007.

35. Basse, E.M. Retssikkerhed i Miljøretten-Hvilke Begreber an Anvendes? In Miljørettens Grundspørgsmål: Bidrag Til En Nordisk Forskeruddannelse; Basse, E.M., Ed.; Gad: København, Denmark, 1994.

36. Raitio, J. The Principle of Legal Certainty in EC Law; Kluwer Academic: Dordrecht, Netherlands, 2010.

37. Kaarlo, T. Self-description and external description of the law. NOFO 2006, 2, 27-43.

38. Tarlock, A.D. Is there a there there in environmental law? JLUEL 2004, 19, 213-254.

39. Beckage, B.; Gross, L.J.; Kauffman, S. The limits to prediction in ecological systems. Ecosphere 2011, 2, art125.

40. Groffman, P.; Baron, J.; Blett, T.; Gold, A.; Goodman, I.; Gunderson, L.; Levinson, B.; Palmer, M.; Paerl, H.; Peterson, G.; Poff, N.; Rejeski, D.; Reynolds, J.; Turner, M.; Weathers, K.; Wiens, J. Ecological thresholds: The key to successful environmental management or an important concept with no practical application? Ecosystems 2006, 9, 1-13.

41. Thrush, S.; Hewitt, J.; Dayton, P.; Coco, G.; Lohrer, A.; Norkko, A.; Norkko, J.; Chiantore, M. Forecasting the limits of resilience: Integrating empirical research with theory. P. Roy. Soc. B-Biol. Sci. 2009, 276, 3209-3217.

42. Walker, B.; Meyers, J.A. Thresholds in ecological and social-ecological systems: A developing database. Ecol. Soc. 2004, 9, Art. 3.

43. Bouleau, G. The WFD dreams: Between ecology and economics. Water. Environ. J. 2008, 22, 235-240. 
44. Howarth, W. Diffuse water pollution and diffuse environmental laws: Tackling diffuse water pollution in England, report by the comptroller and auditor general, HC 186, session 2010-2011, 6 July 2010. J. Environ. Law 2011, 23, 129-141.

45. Gadamer, H-G. Truth and Method, 2nd ed.; Continuum: London, UK, 2004.

46. Noges, P.; van de Bund, W.; Cardoso, A.; Solimini, A.; Heiskanen, A. Assessment of the ecological status of European surface waters: A work in progress. Hydrobiologia 2009, 633, 197-211.

47. Renberg, I.; Bigler, C.; Bindler, R.; Norberg, M.; Rydberg, J.; Segerström, U. Environmental history: A piece in the puzzle for establishing plans for environmental management. J. Environ. Manage. 2009, 90, 2794-2800.

48. Feld, C.; Birk, S.; Bradley, D.; Hering, D.; Kail, J.; Marzin, A.; Melcher, A.; Nemitz, D.; Pedersen, M.; Pletterbauer, F.; Pont, D.; Verdonschot, P.; Friberg, N. From natural to degraded rivers and back again: A test of restoration ecology theory and practice. Adv. Ecol. Res. 2011, 44, 119-209.

49. Solimini, A.; Ptacnik, R.; Cardoso, A. Towards holistic assessment of the functioning of ecosystems under the water framework directive. Trac-Trend. Anal. Chem. 2009, 28, 143-149.

50. Friberg, N.; Bonada, N.; Bradley, D.; Dunbar, M.; Edwards, F.; Grey, J.; Hayes, R.; Hildrew, A.; Lamouroux, N.; Trimmer, M.; Woodward, G. Biomonitoring of human impacts in freshwater ecosystems: The good, the bad and the ugly. Adv. Ecol. Res. 2011, 44, 1-68.

51. Willis, K.; Birks, H. What is natural? The need for a long-term perspective in biodiversity conservation. Science 2006, 314, 1261-1265.

52. Siipi, H. Dimensions of naturalness. Ethics Environ. 2008, 13, 71-103.

53. Moss, B.; Stephen, D.; Alvarez, C.; Becares, E.; Bund, W. V. D.; Collings, S.; Donk, E. V.; Eyto, E. D.; Feldmann, T.; Fernández-Aláez, C.; Fernández-Aláez, M.; Franken, R.; García-Criado, F.; Gross, E. M.; Gyllström, M.; Hansson, L.; Irvine, K.; Järvalt, A.; Jensen, J.; Jeppesen, E.; Kairesalo, T.; Kornijów, R.; Krause, T.; Künnap, H.; Laas, A.; Lill, E.; Lorens, B.; Luup, H.; Rosa Miracle, M.; Nõges, P.; Nõges, T.; Nykänen, M.; Ott, I.; Peczula, W.; Peeters, E.; Phillips, G.; Romo, S.; Russell, V.; Salujõe, J.; Scheffer, M.; Siewertsen, K.; Smal, H.; Tesch, C.; Timm, H.; Tuvikene, L.; Tonno, I.; Virro, T.; Vicente, E.; Wilson, D. The determination of ecological status in shallow lakes - A tested system (ECOFRAME) for implementation of the European Water framework directive. Aquat. Conserv. 2003, 13, 507-549.

54. Segurado, P.; Santos, J.M.; Pont, D.; Melcher, A.; Jalon, D.G.; Hughes, R.; Ferreira, M.T. Estimating species tolerance to human perturbation: Expert judgment versus empirical approaches. Ecol. Indic. 2011, 11, 1623-1635.

55. Mee, L.; Jefferson, R.; Laffoley, D.; Elliott, M. How good is good? Human values and Europe's proposed Marine strategy directive. Mar. Pollut. Bull. 2008, 56, 187-204.

56. Siltala, R. A Theory of Precedent: From Analytical Positivism to a Post-Analytical Philosophy of Law; Hart: Oxford, UK, 2001.

57. Campbell, L.; Gray, N.; Hazen, E.; Shackeroff, J. Beyond baselines: Rethinking priorities for ocean conservation. Ecol. Soc. 2009, 14, Art 14.

58. Papworth, S.; Rist, J.; Coad, L.; Milner-Gulland, E. Evidence for shifting baseline syndrome in conservation. Conserv. Lett. 2009, 2, 93-100. 
59. Nilsson, C. Reservoirs. In Lake Ecosystem Ecology: A Global Perspective; Likens, G., Ed.; Elsevier: Amsterdam, Netherlands, 2010; pp. 625-633.

60. Moss, B. The kingdom of the shore: Achievement of good ecological potential in reservoirs. Freshwater Rev. 2008, 1, 29-42.

61. Doyle, M.; Stanley, E.; Orr, C.; Selle, A.; Sethi, S.; Harbor, J. Stream ecosystem response to small dam removal: Lessons from the Heartland. Geomorphology 2005, 71, 227-244.

62. Keessen, A.; Van Kempen, J.; Van Rijswick, M.; Robbe, J.; Backes, C. European river basin districts: Are they swimming in the same implementation pool? J. Environ. Law 2010, 22, 197-221.

63. Heavily Modified Water Bodies: "Information Exchange on Designation, Assessment of Ecological Potential, Objective Setting and Measures"; Common Implementation Strategy Workshop: Brussels, Belgium, 2009.

64. Palmer, M.; Menninger, H.; Bernhardt, E. River restoration, habitat heterogeneity and biodiversity: A failure of theory or practice? Freshwater Biol. 2010, 55, 205-222.

65. Sundermann, A.; Antons, C.; Cron, N.; Lorenz, A.; Hering, D.; Haase, P. Hydromorphological restoration of running waters: Effects on benthic invertebrate assemblages. Freshwater Biol. 2011, 56, 1689-1702.

66. Fryirs, K.; Brierley, G. Naturalness and place in river rehabilitation. Ecol. Soc. 2009, 14, Art 20.

67. Brierley, G.; Fryirs, K. Don’t fight the site: three geomorphic considerations in catchment-scale river rehabilitation planning. Environ. Manage. 2009, 43, 1201-1218.

68. Westerlund, S. Miljörättsliga Grundfrågor 2.0; IMIR: Björklinge, Sweden, 2003.

69. Carroll, S.; Hendry, A.; Reznick, D.; Fox, C. Evolution on ecological time-scales. Funct. Ecol. 2007, 21, 387-393.

70. Williams, J. Understanding the place of humans in nature. In The Illusory Boundary: Environment and Technology in History; Reuss, M., Cutcliffe, S., Eds.; University of Virginia Press: Charlottesville, VA, USA, 2010; pp. 9-25.

71. Hobbs, R.; Higgs, E.; Harris, J. Novel ecosystems: Implications for conservation and restoration. Trend Ecol. Evol. 2009, 24, 599-605.

72. Schama, S. Landscape and Memory; Fontana: London, UK, 1996.

73. Moss, B.; Hering, D.; Green, A. J.; Aidoud, A.; Becares, E.; Beklioglu, M.; Bennion, H.; Boix, D.; Brucet, S.; Carvalho, L.; Clement, B.; Davidson, T.; Declerck, S.; Dobson, M.; van Donk, E.; Dudley, B.; Feuchtmayr, H.; Friberg, N.; Grenouillet, G.; Hillebrand, H.; Hobaek, A.; Irvine, K.; Jeppesen, E.; Johnson, R.; Jones, I.; Kernan, M.; Lauridsen, T. L.; Manca, M.; Meerhoff, M.; Olafsson, J.; Ormerod, S.; Papastergiadou, E.; Penning, E.; Ptacnik, R.; Quintana, X.; Sandin, L.; Seferlis, M.; Simpson, G.; Triga, C.; Verdonschot, P.; Verschoor, A.; Weyhenmeyer, G. Climate change and the future of freshwater biodiversity in Europe: A primer for policy-makers. Freshwater Rev. 2009, 2, 103-130.

74. Higgs, E. The two-culture problem: Ecological restoration and the integration of knowledge. Restor. Ecol. 2005, 13, 159-164.

75. Hawkins, C.; Olson, J.; Hill, R. The reference condition: Predicting benchmarks for ecological and water-quality assessments. J. N. Am. Benthol. Soc. 2010, 29, 312-343. 
76. Prigogine, I.; Stengers, I. The End of Certainty: Time, Chaos and the New Laws of Nature; The Free Press: New York, NY, USA, 1997.

77. Latour, B. Politics of Nature: How to Bring the Sciences Into Democracy; Harvard University Press: Cambridge, MA, USA, 2004.

78. Fiege, M. Private property and the ecological commons in the American west. In Everyday America: Cultural Landscape Studies After J.B. Jackson; Wilson, C., Groth, P.E., Eds.; University of California Press: Berkeley, CA, USA, 2003.

79. Karr, J.; Dudley, D. Ecological perspective on water quality goals. Environ. Manage. 1981, 5, $55-68$.

80. Moss, B. Water pollution by agriculture. Philos. T Roy. Soc. B. 2008, 363, 659-666.

81. Bisson, P.A.; Reeves, G.H.; Bilby, R.E.; Naiman, R.J. Watershed management and Pacific salmon: Desired futures. In Pacific Salmon and Their Ecosystemsm-Status and Future Options; Stouder, D.J., Bisson, P.A., Naiman, R.J., Eds.; Chapman \& Hall: London, UK, 1996.

82. Norkko, J.; Reed, D.; Timmermann, K.; Norkko, A.; Gustafsson, B.; Bonsdorff, E.; Slomp, C.; Carstensen, J.; Conley, D. A welcome can of worms? Hypoxia mitigation by an invasive species. Global Change Biol. 2012, 18, 422-434.

83. Abell, R.; Blanch, S.; Revenga, C.; Thieme, M. Conservation of aquatic ecosystems. In Lake Ecosystem Ecology: A Global Perspective; Likens, G.E., Ed.; Elsevier: Amsterdam, Netherlands, 2010.

84. Gunderson, L.; Peterson, G.; Holling, C.S. Practicing adaptive management in complex social-ecological systems. In Complexity Theory for a Sustainable Future; Norberg, J., Cumming, G., Eds.; Columbia University Press: New York, NY, USA, 2008.

85. Dellapenna, J.; Gupta, J. The evolution of global water law. In The Evolution of the Law and Politics of Water; Dellapenna, J., Gupta, J., Eds.; Springer: Amsterdam, Netherlands, 2009.

86. World Commission On Environment and Development. Our Common Future; Oxford University Press: New York, NY, USA, 1987.

87. Convention on Biological Diversity: Final Text; Department of Public Information, United Nations: New York, NY, USA, 1992.

88. Palumbo, A. Introduction. In From Government to Governance; Bellamy, R., Palumbo, A., Eds.; Ashgate: Farnham, UK, 2010.

89. Kaika, M. The Water framework directive: A new directive for a changing social, political and economic European framework. Eur. Plan. Stud. 2003, 11, 299-316.

90. Pribán, J. Legal Symbolism: On Law, Time and European Identity; Ashgate: Aldershot, UK, 2007.

91. Melissaris, E. Ubiquitous Law: Legal Theory and the Space for Legal Pluralism; Ashgate: Aldershot, UK, 2009.

92. Nousiainen, K. Time of Law_Time of Experience. In Time, Law and Society: Proceedings of a Nordic Symposium Held May 1994 at Sandbjerg Gods, Denmark; Blegvad, M., Bjarup, J., Eds.; Steiner: Stuttgart, Germany, 1995; pp. 23-39.

93. Laub, B.; Palmer, M. Restoration Ecology of Rivers. In River Ecosystem Ecology: A Global Perspective; Likens, G., Ed.; Elsevier: San Diego, CA, USA, 2010; p. 276. 
94. Hering, D.; Borja, A.; Carstensen, J.; Carvalho, L.; Elliott, M.; Feld, C.; Heiskanen, A.-S.; Johnson, R.; Moe, J.; Pont, D.; Solheim, A. L.; de Bund, W. The European Water framework directive at the age of 10: A critical review of the achievements with recommendations for the future. Sci. Total Environ. 2010, 408, 4007-4019.

95. Elmqvist, T.; Folke, C.; Nyström, M.; Peterson, G.; Bengtsson, J.; Walker, B.; Norberg, J. Response diversity, ecosystem change, and resilience. Front. Ecol. Environ. 2003, 1, 488-494.

96. Bottom, D.; Jones, K.; Simenstad, C.; Smith, C. Reconnecting social and ecological resilience in salmon ecosystems. Ecol. Soc. 14, Art 5.

97. Hendry, A.; Nosil, P.; Rieseberg, L. The speed of ecological speciation. Funct. Ecol. 2007, 21, 455-464.

98. Jowett, I.; Richardson, J.; Boubee, J. Effects of riparian manipulation on stream communities in small streams: Two case studies. New Zeal. J. Mar. Fresh. 2009, 43, 763-774.

99. Davies-Colley, R.; Meleason, M.; Hall, R.; Rutherford, C. Modelling the time course of shade, temperature, and wood recovery in streams with riparian forest restoration. New Zeal. J. Mar. Fresh. 2009, 43, 673-688.

100. Stamou, G.; Asikidis, M.; Argyropoulou, M.; Sgardelis, S. Ecological time versus standard clock time: the asymmetry of phenologies and the life history strategies of some soil arthropods from Mediterranean ecosystems. Oikos 1993, 66, 27-35.

101. Reeves, G.; Duncan, S. Ecological history vs. social expectations: managing aquatic ecosystems. Ecol. Soc. 2009, 14, Art 8.

102. Levin, S. Glossary. In The Princeton Guide to Ecology; Levin, S., Ed.; Princeton University Press: Princeton, NJ, USA, 2009.

103. Ricœur, P. Memory, History, Forgetting; University of Chicago Press: Chicago, IL, USA, 2004.

104. MÖD 2006:44 .

105. MÖD 2007-12-06 M 4643-08 .

106. MÖD 2008-11-19 M 3225-08 .

107. Ruhl, J.B.; Kraft, S.; Lant, C. The Law and Policy of Ecosystem Services; Island Press: Washington, DC, USA, 2007.

108. Moss, B. The art and science of lake restoration. Hydrobiologia 2007, 581, 15-24.

109. Jørgensen, S.E.; Fath, B.; Bastianoni, S.; Marques, J.C.; Muller, F.; Nielsen, S.N.; Patten, B.D.; Tiezzi, E.; Ulanowicz, R.E. A New Ecology: Systems Perspective, 1st ed.; Elsevier: Amsterdam, Netherlands, 2007.

110. Holling, C.S.; Meffe, G. Command and control and the pathology of natural resource management. Conserv. Biol. 1996, 10, 328-337.

111. Simon, A.; Doyle, M.; Kondolf, M.; Shields, F., Jr.; Rhoads, B.; McPhillips, M. Critical evaluation of how the rosgen classification and associated "natural channel design" methods fail to integrate and quantify fluvial processes and channel response. JAWRA 2007, 43, 1117-1131.

112. Krämer, L. The environment and the ten commandments. J. Environ. Law 2008, 20, 5-7.

(C) 2012 by the authors; licensee MDPI, Basel, Switzerland. This article is an open access article distributed under the terms and conditions of the Creative Commons Attribution license (http://creativecommons.org/licenses/by/3.0/). 